\title{
Commuting pays off: Evidence on wage returns to inter-urban and intra-urban commuting
}

\author{
Jakub VONTROBA a , Jiří BALCAR ${ }^{\text {a }}$, Milan ŠIMEK ${ }^{\text {a }}$
}

\begin{abstract}
The distance a person is willing to commute has a direct influence on her/his employment opportunities and wage level. It raises a lot of interesting questions, especially whether intra-urban commuting (due to a welldeveloped transport infrastructure, geographical concentration of job opportunities, etc.) is connected with any wage returns, and how they differ in comparison with those of inter-urban commuting. This article uses three data-sets at national $\left(N_{1}=1,884 ; N_{2}=933\right)$ and local $\left(N_{3}=3,193\right)$ levels from the Czech Republic, and different approximations of commuting in order to contribute to the discussion. It provides robust evidence on positive wage returns to both inter-urban and intra-urban commuting, comparable with Western countries. The differences between large national and limited urban labour markets are reflected in functional form: wage returns are linear for intra-urban and non-linear for inter-urban commuting. The article also explores the validity of different measures of commuting time and distance provided by the on-line application Mapy.cz, and suggests that it represents a suitable approximation in the case of missing or limited data.
\end{abstract}

Key words: commuting, wage returns, job search, urban environment, transport infrastructure, Czech Republic

Article history: Received 18 December 2019, Accepted 25 May 2020, Published 30 June 2020

\section{Introduction}

Migration (i.e. residence relocation) and commuting represent spatially-related coping strategies of individuals adjusting to disequilibriain thelabour market (Termote, 1980), by overcoming geographical distance between residence and work place. Although they are similar in principle, they differ especially in relation to an individual's place of living, their periodicity, and often also the propensity to overcome distance. If the labour market attainable by commuting, i.e. "a repetitive daily trip from a fixed home location to a fixed work location" (Johnston et al., 2009), provides many job opportunities, an individual is motivated not to move out.

A significant lack of job opportunities, however, makes her/him look for employment in a distant labour market, which is usually connected with a permanent or temporary migration, i.e. changing her/his place of living. These factors suggest a substitution relationship between commuting and migration, as the accessibility of labour opportunities through commuting reduces the need for migration, but also relocation within a local labour market can reduce the distance of commuting. On the other hand, migration is always complemented by commuting to overcome the total distance between the original place of living and new workplace, which points to an ambiguous relationship between these two strategies. As a change in place of living occurs occasionally, in comparison with commuting to work on daily basis, and is usually strongly affected by non-workrelated factors, this article limits itself to commuting rather than the trade-offs in migration.

Commuting, or more precisely the willingness to commute, represents a very important factor in an individual's employment and income level, as it directly influences the geographical size of her/his labour market. On one hand, it presents more job offers with a broader wage dispersion (see Stigler, 1961) available to an individual, but on the other hand it brings additional costs connected with commuting. Therefore, an individual is more likely to accept only those job offers providing her/him a wage high enough to cover all financial and non-financial costs of commuting, which is reflected by the positive correlation between wage level and commuting.

It is possible to distinguish intra-urban and inter-urban commuting depending on whether a worker crosses the hometown border on her/his way to work. More than half (53.1\%) of employees live and work in the same town in the Czech Republic, compared to $46.9 \%$ of those commuting

\footnotetext{
${ }^{a}$ Faculty of Economics, VSB - Technical University of Ostrava, Czech Republic (*corresponding author: J. Balcar, e-mail:jiri.balcar@vsb.cz)
} 
outside their hometown (see Appendix 1A). The share of intra-urban commuting is even higher in large cities. For instance, $88.9 \%$ of employees in Ostrava, i.e. the third largest city in the Czech Republic, do not commute outside the city (see Appendix 1B). It can be noted that the apparent differences in transport infrastructure and services inside and outside urban areas may significantly affect the level of financial and mental costs of commuting and corresponding wage levels.

This article employs two representative data-sets from the Czech Republic $(\mathrm{N}=1,884)$ and Ostrava city $(\mathrm{N}=3,193)$ in order to:

a. provide new evidence on the wage returns to commuting in this Central European country; and

b. discuss the impact of transport infrastructure and the geographical size of the labour market on differences in wage returns to inter-urban and intra-urban commuting.

A third data-set $(\mathrm{N}=933)$, using different approximations of commuting time and distance, is used for checking the robustness of the results.

There are several reasons contributing to the importance of this topic. First, there is a substantial empirical body of evidence on positive wage returns to commuting in Western Europe and the United States, but the topic is understudied in East Central Europe. This article represents a contribution to this issue by estimating wage returns to commuting in the Czech Republic and comparing them with returns in Western countries. Second, there is the question whether wage returns even exist for intra-urban commuting, as the commuting distances are usually smaller within the city and urban transport infrastructure is more developed and thus effective. Therefore, the article estimates wage returns to intra-urban and inter-urban commuting separately and compares them. Testing for the functional form of wage returns to commuting reveals significant differences between intra-urban and inter-urban commuting. Third, employing three different data-sets makes it possible to examine commuting from different perspectives and provides a robust and detailed picture on returns to commuting in the Czech Republic. Fourth, two data-sets use data from the online application Mapy.cz as an approximation of commuting time and distance. The comparison of results based on both approximated and real data suggests that data from the application Mapy.cz represents a valid approximation of commuting in the case of missing or limited data.

These aims have been worked out over several sections. The next section provides an overview of empirical evidence on the relationship between commuting and wage level. There follows a description of the data and models employed in this work. The last section is devoted to discussions on the wage returns to inter-urban and intra-urban commuting to work and the factors affecting them.

\section{Empirical evidence on wage returns to commuting}

Commuting to work, as a part of everyday life, strongly affects the quality of workers' lives as it is connected with higher levels of stress (Haider et al., 2013; Higgins et al., 2018; Sposato et al., 2012), lower work performance (Kluger, 1998) and lower life satisfaction (Choi et al., 2013; Nie and SousaPoza, 2018; Stutzer and Frey, 2008). On the other hand, a longer commuting distance is often compensated for by lower costs and a higher standard of housing (Plaut, 2006;
Renkow and Hoover, 2000; Sandow and Westin, 2010) and higher wages (e.g. Morris and Zhou, 2018; Mulalic et al., 2014; Ross and Zenou, 2008).

The positive relationship between commuting distance and wage level can be explained, in accordance with the theory of information (Stigler, 1961), by the higher probability of finding a better paid job by extending the relevant labour market catchment area. At the present, there is extensive empirical evidence on wage returns to commuting in the United States and other developed countries. For instance, Morris and Zhou (2018) quantified wage returns to an hourlong commute in USA at the level of $7.5 \%$, which confirms the $8.2 \%$ wage premium identified for blue-collar workers by Ross and Zenou (2008). Similar results were found also for smaller areas with more developed transport infrastructure, where commuting is more efficient and thus less costly. Timothy and Wheaton (2001) showed that wages vary within US metropolitan areas by up to $15 \%$ and that this variation correlates with commuting.

The results for European countries are similar. A wage premium for an hour-long commute reaches the level of 7-9\% there (Manning, 2003). Gerlach and Stephan (1992) found positive influences of longer commutes on wage levels in Germany, especially in the case of married women (although it has no effect on regional wage disparities, as Niebuhr et al., 2012 showed). This positive relationship was confirmed also for Dutch women (Rouwendal, 1999), where the trade-off between commuting distance and female wages was quantified at the level of 0.12 NLG per kilometre. Laird (2006) provided evidence on positive wage returns to commuting in Scotland, but he pointed out that an increase in an individual's wage level covers her/his commuting costs only partially. Mulalic et al. (2014) examined wage changes connected with company relocation in Denmark: they showed that a one kilometre increase in commuting distance caused by the relocation, had very little effect on wages after one year, but led to $0.15 \%$ wage increase after three years. Ekberg and Widegreen (2019), who analysed the gender pay gap in 71 Swedish local labour markets, identified both longer commuting distance and higher wages in the case of men at the level of the whole economy, especially for particular economic sectors and professional groups.

Evidence on the relationship between wage level and commuting is much more limited for Central and Eastern European countries, however. For instance, Hazans (2004) showed that commuting decreases wage differences between the capital and rest of the country in Estonia and Latvia, but not Lithuania. Evidence from Hungary suggests that wages in areas with high unemployment do not compensate for the costs of commuting (Bartus, 2011), which results in the persistence of unemployment. In the Czech Republic, there is some empirical work on commuting flows and their economic consequences (e.g. Tesla and Horák, 2015; Krejčí and Toušek, 2004; Novák, 2005; Toušek and Kunc, 1999), but the estimation of wage returns to everyday commuting is missing, to the best of authors' knowledge. Studies on commuting flows can be illustrated by the work of Krejčí and Toušek (2004), for example, who analysed changes in commuting to Brno city (the second largest city in the Czech Republic) in the period 1991-2001. They pointed to a rise in the number of commuters travelling longer distances and a simultaneous decrease in commuting intensity from municipalities surrounding Brno. The share of jobs performed by commuters increased in Brno during this period as well. Novák (2005), on the other hand, 
discusses the importance of economic structure, population concentration, the spatial distribution of jobs, and especially highway infrastructure for different aspects of everyday commuting. The above-stated lack of evidence on wage returns to everyday commuting in the Czech Republic is compensated for in the following sections of this article, as they discuss this important topic in detail.

\section{Data and models}

This article employs three data-sets on employees in the Czech Republic in order to provide rigorous and robust evidence on wage returns to commuting to work, distinguishing between the inter-urban and intra-urban cases. It should be noted that the article uses two measures of commuting, i.e. commuting distance and commuting time approximated by:

a. geographical distance and the time necessary to overcome it based on maps and public transport schedules provided by the server Mapy.cz (used in datasets examining wage returns to inter-urban and intraurban commuting separately); and

b. estimations provided by commuters (used for the check on robustness).

The first data source is represented by a tailor-made survey among 1,884 Czech employees aged 25-54 years, focused on wage determinants. These data provide information on the respondents' gross monthly income (in CZK), personal characteristics, education and work experience, preferences related to job, family and life roles, physiological characteristics, psychological traits, and characteristics of family background, households and workplace (hereafter, the 'national data-set'). Data were gathered through standardised face-to-face interviews conducted by the 'FOCUS - Social \& Marketing Research Agency' in October and November, 2011. A quota sampling method was employed: therefore, the sample of respondents is representative for the Czech Republic on the basis of sex, age, education, region and size of municipality of residence. These data were replenished with information on some employers' characteristics (i.e. economic sector, number of employees, date of origin, ownership and legal form). For this purpose, the Albertina Firm Monitor 4/2011 was used, as it provides the relevant information related to the time period when the survey was conducted.

The second data-set stems from a questionnaire survey on satisfaction with life in Ostrava, Czech Republic (hereafter, the 'local data-set'), conducted in February, 2016, as part of preparations of the Strategic Development Plan of the City of Ostrava for the years 2017-2023 (the questionnaire and data are available at http://fajnova.cz). It provides information on the respondents' gross monthly income (in three income categories), education, physical characteristics, preferences, family background and employer characteristics (other variables that are not relevant to this topic are not stated here). Data used in this article are limited only to employees aged 18-64, with permanent residence in Ostrava, who reached at least secondary vocational education (ISCED 3C/ EQF 3); the sample consists of 3,193 observations. As sampling weights were applied, the sample is representative according to sex, age and educational attainment, including sub-samples based on these characteristics.

Unfortunately, neither the national nor the local data-set contains explicit information on commuting to work, such as commuting distance, commuting time or means of transport, but information is provided on place of residence and of work at the level of municipality in the case of the national data- set, and for city districts in the case of the local data-set. Thus, it enables using dummy variables for commuting across municipality or city district borders, as well as approximating distances between municipalities and city districts through the on-line application Mapy.cz. The application provides three different approximations of commuting distance:

a. the length of the shortest route between centres of municipalities/city districts (in kilometres);

b. the time of travel by car (in minutes) to overcome it; and

c. the time of travel by public transport on Monday 7 a.m. (in minutes).

It has to be noted that only employees commuting up to 60 minutes are considered for further analysis in the case of the national data-set in order to focus only on everyday commuters (the Czech Statistical Office, 2013 shows that $97.4 \%$ of the employed Czech population commuted not longer than 60 minutes in 2011); the length of route was limited to the distance covered by car in 60 minutes.

The third data-set stems from an on-line application Mujplat.cz (Tijdens and Osse, 2019), providing a wage benchmark based on information submitted by its users, including their estimation on commuting distance and time (hereafter, the 'Mujplat.cz data-set'). The sample of 933 respondents used in this paper is restricted only to employees aged 25-54 years, living and working in the Czech Republic, who commute no longer than 90 minutes or 75 kilometres in one way; the data were gathered in the year 2014 . Missing data on commuting time and distance lead to a further erosion of the sample to 931 and 785 observations, respectively. As sampling weights were applied, the sample is representative according to sex and age categories, including sub-samples based on these characteristics. Unfortunately, this data-set does not provide detailed information on place of residence and of work, which prevents its use for analysing wage returns to inter-urban and intra-urban commuting separately. Therefore, the Mujplat.cz data-set was used for checking the results, as well as the robustness and validity of commuting measures across different data-sets.

Employing three different data-sets makes it possible to examine the discussed issues from different perspectives and to consider the robustness of the results. At the same time, the data-sets represent a source of the main limitations of the study. First, the results stem from cross-section analyses, as each data-set is related to a specific year, which makes it possible to discuss correlation between wage level and commuting, but not 'causality'. Second, the lack of information on previous migration behaviours, i.e. changes in place of residence, prevent us from considering the wage returns to a combination of migration and commuting, as a strategy for overcoming geographical distance between labour force and work place (see Introduction). Therefore, the place of residence is taken as an exogenous factor here. Third, the data employed in this article enables estimation of the wage premium connected with commuting, but the lack of information on commuting costs prevents us from quantification of its net benefits. Fourth, the place of residence and work is specified at the level of municipality and city district in the case of the national and local data-sets, respectively. Information on actual addresses would increase the accuracy of the results significantly. Although it is necessary to treat these results with respect to these limitations, the findings of this article may still represent a significant contribution to the discussion on wage returns to intra-urban and inter-urban commuting and their differences. 
These data-sets (see Appendix 1 for definitions and descriptive statistics of all variables) were used for an estimation of Mincer-type OLS models (in the case of the national data-set and Mujplat.cz data-set) and ordinal logit models (in the case of the local data-set), explaining ln gross monthly wage (OLS models) or gross monthly wage category (ordinal logit models) by commuting, education and work experience, physical characteristics, non-cognitive skills and life preferences, family and background characteristics, employer and job characteristics, and location (see Equation 1). It should be noted that variables approximating the particular components of the wage model differ depending on the data-set (for detailed specification of models see variables in Tabs. 1, 2 and 4).

$$
\begin{gathered}
\text { ln gross monthly wage } \\
\text { or } \\
\text { gross monthly wage category }
\end{gathered}=f\left(\begin{array}{c}
\text { commuting to work, } \\
\text { education and work experience, } \\
\text { physical characteristics, } \\
\text { noncognitive skills and life preferences, } \\
\text { family and background charactristics, } \\
\text { employer and job characteristics, } \\
\text { location }
\end{array}\right)
$$

A high level of attention was paid to data verification and model specification. First, a check of all data-sets was performed in order to exclude observations with unrealistic (extreme) values and obvious measurement errors. Although model specification was primarily based on theoretical assumptions and empirical evidence on wage determinants, the inclusion of variables into the model was influenced also by a check for correlation between explanatory variables in order to avoid potential problem of multi-collinearity, and a check for empty and small cells in order to support model stability. All OLS models were further tested for specification errors (Ramsey RESET test and link test), multi-collinearity (VIF test), heteroscedasticity (Breusch-Pagan test) and autocorrelation (run-test). Estimations based on the national data-set embodied no violation of the OLS assumptions, but heteroscedasticity and autocorrelation were identified in models using the Mujplat.cz data-set. An appropriate method of robust standard errors (clustered by age of respondents) was applied in these cases. Ordinal logit models using the local data-set were tested for specification error (link test), multi-collinearity (VIF test) and goodness of fit: no violations of the model assumptions were found.

\section{Results and discussion}

\subsection{Wage returns to inter-urban and intra-urban commuting}

Empirical literature shows that there are many factors, such as good health, education, work experience, developed non-cognitive skills or better information on job opportunities and willingness to commute (see Balcar, 2012, for a review), that have a positive impact on workers' productivity and wages. This section presents estimations of wage returns to inter-urban commuting in the Czech Republic (using the national data-set), and intra-urban commuting in Ostrava (using the local data-set). It enables us not only to provide evidence on wage returns to commuting, but also to discuss them, considering different conditions of inter-urban and intra-urban commuting, such as the quality and thus efficiency of transport infrastructure.

Estimations of wage returns to inter-urban commuting in the Czech Republic, based on the national data-set, are presented in Table 1 . Model 1 shows that employees commuting to work out of the municipality of their residence gain $5.2 \%$ higher wages, compared to their counterparts living and working in the same municipality. As information on commuting distance within municipalities is not available, further analysis will be limited only to individuals commuting out of the municipality. Models 2-4 approximate commuting distance by three different variables:

a. length of the shortest route between municipalities of residence and of work (in kilometres);

b. time of travel by car (in minutes) necessary to overcome it; and

c. time of travel by public transport (in minutes).

The results reveal that only time of travel by car is significantly correlated with commuters' wage level. There is a wage bonus at the level of $0.19 \%$ for each minute of commuting between municipalities of residence and work (the estimated wage bonus of $11.4 \%$ for an hour-long commute corresponds to the results of Manning, 2003, especially when potential bias connected with focusing only on inter-urban commuters is considered). Assuming that

i. time and not the route length is more related to the real costs of commuting, and

ii. travelling by car is more efficient and thus preferred to public transport in the case of inter-urban commuting, it is no surprise that the other two approximations of commutation distance are less statistically significant, i.e. insignificant in this case.

In fact, the non-significance of the length of the route in kilometres is due to a wrong functional form, as will be shown later. The estimation of linear returns, however, to the route distance of $0.11 \%$ (statistically insignificant here) is similar to the results reported by Mulalic et al. (2014). It can be concluded that employees commuting out of the municipality of their residence earn higher wages, the level of which is positively correlated with the time spent in the car on the road to work.

Wage returns to commuting in Ostrava City, estimated using the local data-set, can be found in Table 2. Model 5 supports conclusions presented above, as it indicates that individuals commuting to work out of Ostrava have 1.6 times higher odds of belonging to a higher wage category compared with those working within Ostrava city. It means, using average marginal predictions, that commuting out of Ostrava decreases the probability of belonging to the lowest income category (up to $20,000 \mathrm{CZK}$ ) by $-8.2 \%$, while it increases the probability of belonging to the highest income category (30,000 CZK and more) by $4.8 \%$. Model 6 focuses exclusively on intra-urban commuting, i.e. employees commuting within Ostrava city. It reveals that there is no statistically significant difference in wage category between individuals living and working in the same city district and those working out of the city district of their residence. It suggests that commuting distance within and between Ostrava's districts does not need to be significantly different and crossing the administrative lines of city districts itself do not matter. Models 7-9 employ various approximations of commuting distance in order to estimate their impact on wage level for employees commuting out of the city district of their residence. In the case of Ostrava city, route length as well as travel time, for both car and public transport, were found to be statistically significant predictors of wage category. The statistical significance of all three approximations of the commuting distance, compared to the estimations based on the national data-set presented in Table 1, suggests that the urban transport infrastructure is more efficient than that for the country as a whole. The results show that the longer the commuting distance is, the higher is the probability 
of belonging to the higher wage category. As there is no statistically significant difference between employees commuting inside and outside of their residential city district (see Model 6), this conclusion is generally valid for the whole population of employees working in Ostrava.
The influence of commuting distance on wage category is visualised in Figure 1. For instance, average marginal predicted probability of having gross monthly wage at the level of 30,000 CZK or more (the highest income category) is $23 \%$ for employees commuting by car for 30 minutes in one

\begin{tabular}{lcccc}
\hline VARIABLES & $\begin{array}{c}\text { (1) ln gross } \\
\text { monthly wage }\end{array}$ & $\begin{array}{c}\text { (2) ln gross } \\
\text { monthly wage }\end{array}$ & $\begin{array}{c}\text { (3) ln gross } \\
\text { monthly wage }\end{array}$ & $\begin{array}{c}\text { (4) ln gross } \\
\text { monthly wage }\end{array}$ \\
\hline
\end{tabular}

\section{Commuting}

Commuting out of residence municipality (dummy)

$0.0501^{* * *}$

(0.016)

Length of the shortest route (kilometres)

Time of travel by car (minutes)

Time of travel by public transport (minutes)

Education, work experience and cognitive skills

Years of schooling

Tenure

Tenure squared

Other work experience

Other work experience squared

Grades from math at age 15 (1 best, 5 worst)

Physical characteristics ${ }^{\text {I. }}$

Female

Non-cognitive skills and life preferences ${ }^{\text {II. }}$

Family and background characteristics ${ }^{\text {III. }}$

Employer and job characteristics ${ }^{\text {IV. }}$

Location $v$.

Constant

Observations

Adj. $R^{2}$

\begin{tabular}{cc}
$0.0242^{* * * *}$ & $0.0336^{* * *}$ \\
$(0.004)$ & $(0.006)$ \\
$0.0132^{* * *}$ & $0.0209^{* * *}$ \\
$(0.003)$ & $(0.004)$ \\
$-0.0002^{* *}$ & $-0.0004^{* * *}$ \\
$(0.000)$ & $(0.000)$ \\
$0.0070^{* * *}$ & $0.0110^{* * *}$ \\
$(0.002)$ & $(0.004)$ \\
$-0.0002^{* *}$ & $-0.0003^{* *}$ \\
$(0.000)$ & $(0.000)$ \\
$-0.0327^{* * *}$ & $-0.0471^{* * *}$ \\
$(0.009)$ & $(0.014)$ \\
yes & yes \\
$-0.1325^{* * *}$ & $-0.1279^{* * *}$ \\
$(0.023)$ & $(0.034)$ \\
yes & yes \\
yes & yes \\
yes & yes \\
yes & $8.1747^{* * *}$ \\
$8.3614^{* * *}$ & $0.348)$ \\
$(0.227)$ & 852 \\
0.524 & 0.584 \\
\hline
\end{tabular}

$0.0019 * *$

$(0.001)$

0.0008

(0.001)

\begin{tabular}{|c|c|}
\hline $0.0336^{* * *}$ & $0.0312^{* * *}$ \\
\hline$(0.006)$ & $(0.007)$ \\
\hline $0.0211^{* * * *}$ & $0.0215^{* * * *}$ \\
\hline$(0.004)$ & $(0.004)$ \\
\hline$-0.0004^{* * *}$ & $-0.0004^{* *}$ \\
\hline$(0.000)$ & $(0.000)$ \\
\hline $0.0110^{* * * *}$ & $0.0097^{* *}$ \\
\hline$(0.004)$ & $(0.004)$ \\
\hline$-0.0003^{* *}$ & $-0.0003^{* *}$ \\
\hline$(0.000)$ & $(0.000)$ \\
\hline$-0.0462 * * *$ & $-0.0575^{* * *}$ \\
\hline$(0.014)$ & $(0.016)$ \\
\hline yes & yes \\
\hline$-0.1285^{* * * *}$ & $-0.1321^{* * *}$ \\
\hline$(0.034)$ & $(0.038)$ \\
\hline yes & yes \\
\hline yes & yes \\
\hline yes & yes \\
\hline yes & yes \\
\hline $8.1526^{* * * *}$ & $8.5700^{* * * *}$ \\
\hline$(0.347)$ & $(0.401)$ \\
\hline 852 & 732 \\
\hline 0.522 & 0.479 \\
\hline
\end{tabular}

Tab. 1: Wage returns to commuting based on the national data-set (regression coefficients reported) Source: authors' computations

Notes: Robust standard errors in parentheses; *** $p<0.01$, ** $p<0.05$, * $p<0.1$; See Appendix 2 for full results; I - Health limitation of work performance, Difference between individual's height and average gender height, BMI, BMI2; II - Strong need to excel and be better than others, Persistence in following difficult goals, Self-esteem, Locus of control, Feeling of personal responsibility for ensuring an adequate income, Feeling of personal responsibility for ensuring everyday housework and taking care of children, Highest life priority (family, work, free time); III - Relationship status, Number of children in 5 age categories, Number of siblings, Mother tongue; IV - Number of employees, Ownership, Natural person dummy, Age of firm/institution, Prevailing economic activity (1-digit NACE), Occupation (1-digit ISCO), Field of education and job match, Workload (scheduled working hours per week), Difference in number of hours really devoted to work and official workload, Rate of subjectivity in wage system, Absenteeism, Relation with superior/manager; V-Region according to Nomenclature of Territorial Units for Statistics (NUTS 3), Residence town size, Job opportunities 


\begin{tabular}{|c|c|c|c|c|c|}
\hline VARIABLES & $\begin{array}{l}\text { (5) gross } \\
\text { monthly } \\
\text { wage } \\
\text { category }\end{array}$ & $\begin{array}{l}\text { (6) gross } \\
\text { monthly } \\
\text { wage } \\
\text { category }\end{array}$ & $\begin{array}{l}\text { (7) gross } \\
\text { monthly } \\
\text { wage } \\
\text { category }\end{array}$ & $\begin{array}{l}\text { (8) gross } \\
\text { monthly } \\
\text { wage } \\
\text { category }\end{array}$ & $\begin{array}{l}\text { (9) gross } \\
\text { monthly } \\
\text { wage } \\
\text { category }\end{array}$ \\
\hline \multicolumn{6}{|l|}{ Commuting } \\
\hline Commuting out of Ostrava (dummy) & $\begin{array}{l}1.571^{* *} \\
(0.344)\end{array}$ & & & & \\
\hline Commuting out of borough of residence (dummy) & & $\begin{array}{l}1.114 \\
(0.152)\end{array}$ & & & \\
\hline Length of the shortest route (kilometres) & & & $\begin{array}{l}1.051^{* *} \\
(0.0248)\end{array}$ & & \\
\hline Time of travel by car (minutes) & & & & $\begin{array}{l}1.055^{* * * *} \\
(0.0213)\end{array}$ & \\
\hline Time of travel by public transport (minutes) & & & & & $\begin{array}{l}1.018^{* * *} \\
(0.0066)\end{array}$ \\
\hline Education and potential work experience & & & & & \\
\hline Years of schooling & $\begin{array}{l}1.485^{* * * *} \\
(0.0298)\end{array}$ & $\begin{array}{l}1.497^{* * *} \\
(0.0331)\end{array}$ & $\begin{array}{l}1.528^{* * *} \\
(0.0417)\end{array}$ & $\begin{array}{l}1.531^{* * * *} \\
(0.0420)\end{array}$ & $\begin{array}{l}1.533^{* * *} \\
(0.0420)\end{array}$ \\
\hline Age 18-24 years & $\begin{array}{l}0.152^{* * * *} \\
(0.0619)\end{array}$ & $\begin{array}{l}0.180^{* * * *} \\
(0.0761)\end{array}$ & $\begin{array}{l}0.259^{* * *} \\
(0.123)\end{array}$ & $\begin{array}{l}0.257^{* * *} \\
(0.121)\end{array}$ & $\begin{array}{l}0.243^{* * *} \\
(0.115)\end{array}$ \\
\hline Age $25-34$ years & $\begin{array}{l}0.378^{* * * *} \\
(0.0997)\end{array}$ & $\begin{array}{l}0.394^{* * *} \\
(0.105)\end{array}$ & $\begin{array}{l}0.429^{* * *} \\
(0.136)\end{array}$ & $\begin{array}{l}0.431^{* * *} \\
(0.136)\end{array}$ & $\begin{array}{l}0.427^{* * * *} \\
(0.133)\end{array}$ \\
\hline Age $35-44$ years & $\begin{array}{l}0.906 \\
(0.219)\end{array}$ & $\begin{array}{l}0.862 \\
(0.203)\end{array}$ & $\begin{array}{l}1.007 \\
(0.280)\end{array}$ & $\begin{array}{l}1.015 \\
(0.280)\end{array}$ & $\begin{array}{l}1.023 \\
(0.280)\end{array}$ \\
\hline Age $45-54$ years & $\begin{array}{l}1.155 \\
(0.249)\end{array}$ & $\begin{array}{c}1.145 \\
(0.253)\end{array}$ & $\begin{array}{l}1.367 \\
(0.352)\end{array}$ & $\begin{array}{c}1.367 \\
(0.351)\end{array}$ & $\begin{array}{c}1.360 \\
(0.347)\end{array}$ \\
\hline $\begin{array}{l}\text { Age } 55-64 \text { years } \\
\text { Physical characteristics }\end{array}$ & baseline & baseline & baseline & baseline & baseline \\
\hline Female & $\begin{array}{l}0.283^{* * *} \\
(0.0354)\end{array}$ & $\begin{array}{l}0.301^{* * *} \\
(0.0407)\end{array}$ & $\begin{array}{l}0.338^{* * *} \\
(0.0510)\end{array}$ & $\begin{array}{l}0.336^{* * * *} \\
(0.0508)\end{array}$ & $\begin{array}{l}0.338^{* * *} \\
(0.0510)\end{array}$ \\
\hline Life preferences ${ }^{\mathrm{I}}$. & yes & yes & yes & yes & yes \\
\hline Family and background characteristics ${ }^{\text {II. }}$ & yes & yes & yes & yes & yes \\
\hline Employer characteristics ${ }^{\text {III. }}$ & yes & yes & yes & yes & yes \\
\hline City district & yes & yes & yes & yes & yes \\
\hline Constant cut1 & $\begin{array}{l}53.74^{* * *} \\
(26.48)\end{array}$ & $\begin{array}{l}48.69^{* * *} \\
(26.16)\end{array}$ & $\begin{array}{l}111.6^{* * *} \\
(72.75)\end{array}$ & $\begin{array}{l}148.0^{* * *} \\
(100.6)\end{array}$ & $\begin{array}{l}142.0^{* * * *} \\
(93.72)\end{array}$ \\
\hline Constant cut2 & $\begin{array}{l}614.0^{* * *} \\
(310.6)\end{array}$ & $\begin{array}{l}638.7^{* * *} \\
(356.3)\end{array}$ & $\begin{array}{l}1,716^{* * *} \\
(1.175)\end{array}$ & $\begin{array}{l}2,292^{* * * *} \\
(1.645)\end{array}$ & $\begin{array}{l}2,207^{* * * *} \\
(1.535)\end{array}$ \\
\hline Observations & 3,193 & 2,838 & 2,057 & 2,057 & 2,057 \\
\hline Adj. McFadden $\mathrm{R}^{2}$ & 0.183 & 0.191 & 0.189 & 0.191 & 0.192 \\
\hline
\end{tabular}

Tab. 2: Wage returns to commuting based on the local data-set (odds ratios reported)

Source: authors' computations

Notes: Robust standard errors in parentheses; *** $p<0.01$, ** $p<0.05$, * $p<0.1$; See Appendix 2, Table $2 B$ for full results; I - Highest life priority (family, work, free time), II - Cohabitation with life partner, Children in 4 age categories (dummy variables), III - Prevailing economic activity (1-digit NACE), Sector of economic activities (Private, Public, Non-profit) 
direction every day, compared to $12 \%$ for those commuting only 10 minutes or $8 \%$ for non-commuters.

\subsection{Non-linear returns to commuting}

To date, we have confirmed that everyday commuting to work is connected with a statistically significant wage premium in the Czech Republic, regardless of whether interurban or intra-urban commuting is discussed. This finding raises a new interesting question connected with the very practical aspect of commuting. What commuting distance is connected to the highest wage returns?

Answering this question requires analysing mechanisms behind the decision-making process on commuting to work. Although there are many factors influencing workers' willingness to commute, they are reflected in three fundamental commuting strategies:

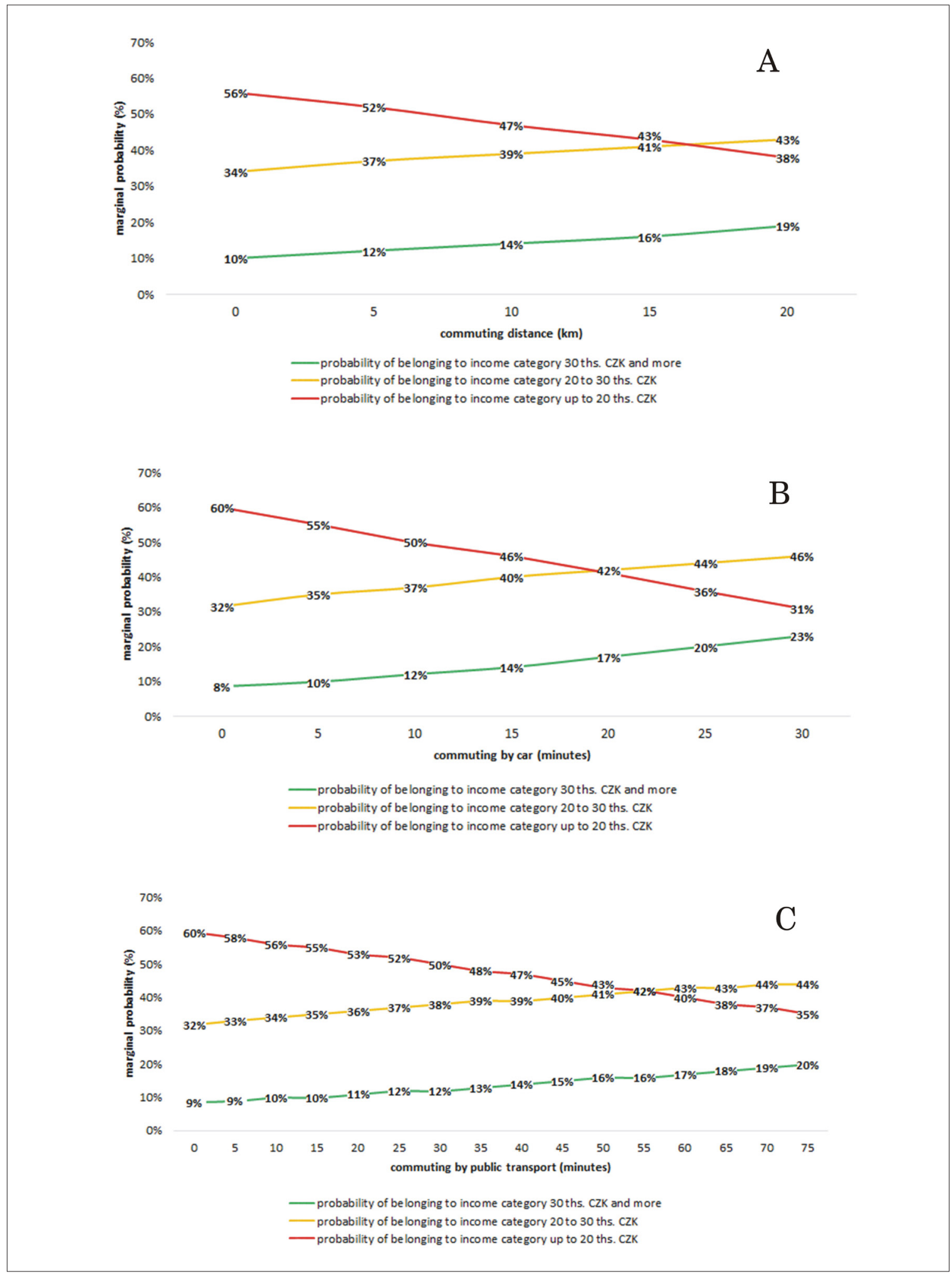

Fig. 1: Predicted probabilities of belonging into wage categories depending on commuting distance (A: Length of the shortest route - in kilometres; B: Time of travel by car - in minutes; C: Time of travel by public transport-in minutes) Source: authors' computations 
a. minimising commuting distance at the expense of a lower wage level;

b. maximising wage level by the broadening of a search perimeter and thus considering more job offers; and

c. getting a job and acquiring at least some income, in the case of a serious lack of job opportunities, even with the costs of a long commuting distance.

It can be expected that the broadening of the job-search perimeter, due to a gradual coverage of the dispersion range in job offers on the labour market, will lead to an increase of potential wages at a decreasing rate (see Stigler, 1961). It suggests that there is a perimeter size representing an imaginary frontier for optimal searching activity (given not only by a decreasing variability of job offers, but also other factors such as increasing searching costs or the spatial distribution of municipalities), and all wage-maximising decisions are taken inside this perimeter. In such a case, quantification of commuting distance providing the highest wage returns and its comparison with real commuting behaviour, will provide interesting information on commuting in the Czech Republic. Beyond the perimeter frontier, commuting provides non-maximal wage returns, which may be still accepted by workers facing a lack of job opportunities. These mechanisms suggest that the relationship between wage level and commuting distance may be non-linear.

Firstly, the non-linearity of wage returns to commuting was tested for inter-urban commuting in the Czech Republic, i.e. using a sub-sample of employees living and working in different municipalities. The linear form of the three approximations of commuting distance in Models 2-4 in Table 1 were replaced by their quadratic forms and re-estimated (see Models $2 \mathrm{~A}-4 \mathrm{~A}$ in Tab. 3). The results support the hypothesis on non-linearity between inter-urban commuting distance and wage level. Both linear and quadratic terms of the length of the shortest route (in kilometres) and time of travel by car (in minutes) was found to be highly statistically significant (compare Models 2-3 with 2A-3A). On the other hand, time of travel by public transport remains statistically insignificant. Estimations of Models 2A and $3 \mathrm{~A}$ show that wage returns to commuting increase up to a distance of 35.1 kilometres or 31.5 minutes by car, where they reach level of $11.6 \%$ and $16.6 \%$ respectively. The real commuting distances, however, are significantly shorter as the sample mean reaches $17.5 \mathrm{~km}$ (standard deviation: 13.5) and 18.5 minutes by car (standard deviation: 11.0). This discrepancy may be ascribed to commuting costs, which can be easily illustrated. The everyday commuting of 35.1 kilometres in one way, i.e. the total distance of $1,474 \mathrm{~km}$ per month $(35.1 \mathrm{~km}$ in one-way $\times 2$ for return journey $\times 21$ working days per month), was connected with a monthly wage bonus of $2,261 \mathrm{CZK}$ in 2011 (based on re-estimation of Model 2A with income in CZK as a dependent variable: regression coefficient of the linear term of the length of the shortest route in $\mathrm{km}$ reached the value of $136.02, \mathrm{P}=0.003$ and quadratic term $-2.04, \mathrm{P}=0.006$; the estimation is not shown here). It means that the commuting costs would be fully covered by this wage premium only if they did not exceed the level of $1.53 \mathrm{CZK}$ per kilometre. As the wage returns to commuting grow at a decreasing rate, the shorter distance is connected with higher coverage of commuting costs. For instance, a commuting distance of $21 \mathrm{~km}$ is connected with a wage premium of $2.2 \mathrm{CZK}$ per kilometre, which perfectly fits the costs of unleaded petrol in 2011 (consumption of 7

\begin{tabular}{|c|c|c|c|c|c|c|}
\hline \multirow{2}{*}{ VARIABLES } & \multicolumn{3}{|c|}{$\begin{array}{l}\text { Czech Republic the national data-set) } \\
\text { regression coefficients of OLS models }\end{array}$} & \multicolumn{3}{|c|}{$\begin{array}{l}\text { Ostrava (the local data-set) } \\
\text { odds ratio of ordered logit models }\end{array}$} \\
\hline & $\begin{array}{l}(2 \mathrm{~A}) \text { ln gross } \\
\text { montly wage }\end{array}$ & $\begin{array}{l}\text { (3A) ln gross } \\
\text { montly wage }\end{array}$ & $\begin{array}{l}(4 \mathrm{~A}) \ln \text { gross } \\
\text { montly wage }\end{array}$ & $\begin{array}{l}\text { (7A) ln gross } \\
\text { montly wage } \\
\text { category }\end{array}$ & $\begin{array}{l}\text { (8A) ln gross } \\
\text { montly wage } \\
\text { category }\end{array}$ & $\begin{array}{c}\text { (9A) ln gross } \\
\text { montly wage } \\
\text { category }\end{array}$ \\
\hline \multicolumn{7}{|l|}{ Commuting } \\
\hline \multirow[t]{2}{*}{ Length of the shortest route $(\mathrm{km})$} & $0.0066^{* * *}$ & & & 1.043 & & \\
\hline & $(0.002)$ & & & $(0.0846)$ & & \\
\hline \multirow[t]{2}{*}{ Length of the shortest route squared } & $-0.0001^{* * *}$ & & & 1.000 & & \\
\hline & $(0.000)$ & & & $(0.0038)$ & & \\
\hline \multirow[t]{2}{*}{ Time of travel by car (min) } & & $0.0106^{* * *}$ & & & 1.080 & \\
\hline & & $(0.003)$ & & & $(0.0833)$ & \\
\hline \multirow[t]{2}{*}{ Time of travel by car squared } & & $-0.0002^{* * *}$ & & & 0.999 & \\
\hline & & $(0.000)$ & & & $(0.0027)$ & \\
\hline \multirow[t]{2}{*}{ Time of travel by public transport (min) } & & & 0.0010 & & & $1.047^{*}$ \\
\hline & & & $(0.003)$ & & & $(0.0248)$ \\
\hline \multirow[t]{2}{*}{ Time of travel by public transport squared } & & & -0.0000 & & & 1.000 \\
\hline & & & $(0.000)$ & & & $(0.0003)$ \\
\hline $\begin{array}{l}\text { Other control variables as in original } \\
\text { model }\end{array}$ & Model 2 & Model 3 & Model 4 & Model 7 & Model 8 & Model 9 \\
\hline Observations & 852 & 852 & 732 & 2,057 & 2,057 & 2,057 \\
\hline Adj. $R^{2}$ & 0.525 & 0.527 & 0.478 & & & \\
\hline Adj. McFadden $\mathrm{R}^{2}$ & & & & 0.189 & 0.191 & 0.192 \\
\hline
\end{tabular}

Tab. 3: Non-linear relationships between commuting and gross monthly wage Source: authors' computations

Notes: Robust standard errors in parentheses; $* * * p<0.01, * * p<0.05, * p<0.1$ 
litres of fuel per $100 \mathrm{~km}$ is assumed), but still do not cover other commuting costs, such as value of time, car wear, etc. It suggests that 'real' commuting behaviour represents a compromise between economically rational preference of short commuting distance and the need to find suitable employment.

As a second note, the non-linearity of the relationship between commuting distance and wage level was tested also for intra-urban commuting within Ostrava City, i.e. using a sub-sample of employees living and working in different city districts. The quadratic terms in all three models (Models 7A-9A in Tab. 3), however, were found to be statistically insignificant, suggesting that the examined relationship is linear. There are two possible explanations for this result:

i. workers screen all job offers in Ostrava (considering their wage variability) at once, as it represents one local labour market, not gradually in different city districts; and

ii. commuting distances within Ostrava City are not large enough to allow the quadratic term to have some significant impact on wages. In that case, the more willing is a worker to commute, the higher wage she/he will have.

\subsection{Robustness check}

It can be concluded that both national and local data-sets identified positive and statistically significant wage bonuses for inter-urban commuting, approximated by crossing municipality borders on the way to work (Models 1 and 5). Geographical distance between municipalities/city districts of residence and work (Models 2A and 7) and the time necessary to cover this distance by car (Models $3 \mathrm{~A}$ and 8) were also found to be significantly correlated with wage level, although the functional form of this relationship was different for inter-urban and intra-urban commuting. Commuting time by public transport was associated with wage level only in the case of the local data-set, which correspond with greater efficiency of urban public transport services compared to inter-urban public transport. Despite using two different data-sets and four approximations of commuting, the results show the same robust picture - a greater willingness to commute is correlated with higher wage returns.

Neither the national nor the local data-set contains explicit information on commuting, which was approximated by the distance between municipalities / city districts of residence and work and time taken using information from the server Mapy.cz. As one may doubt the validity of this approximation, the wage model was re-estimated employing the Mujplat. cz data-set, which contains information on commuting time (6 categories per 15 minutes) and commuting distance (3 categories per 25 kilometres) provided by workers themselves. The lack of information on place of residence and work prevented us from using this data-set for estimating wage returns to inter-urban and intra-urban commuting separately. Results based on this data-set (see Tab. 4) provide further evidence on wage returns to commuting in the Czech Republic, as well as the opportunity to consider the validity of the approximation of commuting used in this article and the robustness of the results presented above.

The model re-estimation using the Mujplat.cz data-set (see Tab. 4) confirms positive and statistically significant relationship between wage level and commuting distance (Models 10-11), but not commuting time (Model 12-13). The results show that an increase in commuting distance by 25 kilometres category results in a $7.4 \%$ wage bonus, i.e. at least $0.3 \%$ per 1 kilometre (Model 10 ). The wage returns to commuting are not linear, however, and reach a peak at a commuting distance between 25 and 50 kilometres with returns at the level of $12.6 \%$ (Model 11), which corresponds with the findings for inter-urban commuting (see Model 2A). In addition, this data-set also confirms the previous finding that the majority of employees commute below the wagemaximising distance, as $87.5 \%$ of them commute up to 25 kilometres.

As stated above, no statistically significant relationship was found between wage level and commuting time, regardless of whether the linear (Model 12) or non-linear (Model 13) form was considered. The statistical non-significance of the commuting time coefficient can be due to a mixture of means of transport used for commuting by employees in the sample (including walking, biking, driving a car, public transport, etc.), which leads to less precise approximation of commuting distance and related costs. The national and local data-sets, on the contrary, approximate commuting time for specific means of transport, i.e. commuting time by car and commuting time by public transport, and found commuting time variables highly significant, with the exception of commuting by public transport in the case of inter-urban commuting. It can be concluded that results in Table 4 are not in contradiction with estimations based on the national and local data-sets, and tend to support their robustness.

\section{Conclusions}

A willingness to commute and subsequently real commuting behaviour represent very important factors in an individual's employment and wage level, as they determine the size of her/his labour market. There is a substantial empirical body of research on wage returns to commuting for USA and Western Europe, but not for Central and Eastern Europe. Moreover, most empirical studies discuss the wage returns to commuting using national data, which provide very important information on general conditions in the labour market, but do not explore its validity for specific conditions in urban labour markets (such as more developed transport infrastructure, limited size and the geographical concentration of job opportunities). This article responds to both the limitations of current empirical literature on commuting in East Central Europe by providing evidence on wage returns to commuting in the Czech Republic, and by discussing wage returns to inter-urban and intra-urban commuting separately. Some attention was also devoted to specific topics such as the functional form of the relationship between commuting and wage level, the commuting distance maximising wage returns, and their differences on national and local labour markets.

Using data from the Czech Republic and Ostrava City, as national and local level data-sets, we have provided robust evidence on positive and statistically significant wage returns to both inter-urban and intra-urban commuting, which corresponds to returns in Western countries. The significance and magnitude of the regression coefficients suggest that commuting by car compared to public transport represents a more efficient means of travelling to work, although public transport is a viable alternative for intraurban commuters.

The results also revealed that different spatial characteristics of large national and limited urban labour markets are reflected in the functional forms of the 


\begin{tabular}{lcccc}
\hline VARIABLES & $\begin{array}{c}(10) \text { gross } \\
\text { monthly wage }\end{array}$ & $\begin{array}{c}\text { (11) gross } \\
\text { monthly wage }\end{array}$ & $\begin{array}{c}\text { (12) gross } \\
\text { monthly wage }\end{array}$ & $\begin{array}{c}\text { (13) gross } \\
\text { monthly wage }\end{array}$ \\
\hline
\end{tabular}

Commuting

Commuting distance: linear trend (per $25 \mathrm{~km}$ category)

$0.074^{* *}$

$(0.034)$

Commuting distance: $0-25 \mathrm{~km}$
baseline
$0.126^{* * *}$
$(0.051)$
0.056
(0.068)

Commuting distance: $50-75 \mathrm{~km}$

Commuting time: linear trend (per 15 min category)

0.009

$(0.012)$

Commuting time: 0-15 min

Commuting time: $15-30$ min

Commuting time: $30-45 \mathrm{~min}$

(0.040)

0.006

Commuting time: 45-60 min

(0.046)

0.124

Commuting time: $60-75 \mathrm{~min}$

(0.081)

Commuting time: 75-90 min

0.089

$(0.077)$

Education and work experience

Primary education

$$
\begin{gathered}
-0.344^{* * *} \\
(0.083) \\
-0.187^{* * *} \\
(0.052) \\
\text { baseline }
\end{gathered}
$$

$$
\begin{array}{r}
0.011^{*} \\
(0.006) \\
-0.000^{*} \\
(0.000)
\end{array}
$$

$$
\begin{gathered}
-0.161^{* * *} \\
(0.033)
\end{gathered}
$$

Family characteristics ${ }^{\text {I. }}$

Employer and job characteristics ${ }^{\text {II. }}$

Location ${ }^{\text {III. }}$

Constant

Observations

Adj. $R^{2}$

$\begin{array}{cc}\text { yes } & \text { yes } \\ \text { yes } & \text { yes } \\ \text { yes } & \text { yes } \\ 9.408^{* * *} & 9.470^{* * *} \\ (0.178) & (0.177) \\ 785 & 785 \\ 0.521 & 0.522\end{array}$

$-0.308^{* * *}$
$(0.061)$
$-0.194^{* * *}$
$(0.047)$
baseline

$-0.309 * * *$

(0.062)

$-0.196^{* * * *}$

(0.047)

baseline

0.011
$(0.007)$
$-0.000^{*}$
$(0.000)$

$$
0.010
$$

0.010

(0.006)

(0.006)

$-0.000$

$-0.000$

(0.000)

(0.000)

$$
-0.168^{* * *}
$$$$
-0.168^{* * * *}
$$$$
\text { (0.032) }
$$

(0.032)

yes

yes

yes

yes

yes

yes

$9.462^{* * *}$

$9.467 * * *$

(0.187)

(0.177)

931

0.508

Tab. 4: Wage returns to commuting based on the Mujplat.cz data-set (regression coefficients reported) Source: authors' computations

Notes: Robust standard errors in parentheses; ${ }^{* *} p<0.01,{ }^{* *} p<0.05,{ }^{*} p<0.1$; See Appendix 2 for full results; I - Marital status; II - Part-time job, Real working hours per week, Permanent employment contract, Occupation skill level, Supervisory position, Sector of economic activities (Private, Public, Non-profit), Number of employees, Ownership; III - NUTS3 region, Residence town size, Job opportunities 
relationships between commuting distance and wage level. Non-linear wage returns to inter-urban commuting made it possible to quantify a commuting distance between municipalities associated with the highest wage returns. They are 35.1 kilometres or 31.5 minutes of travel by car in one direction, which are connected with a wage bonus at the level of $11.6 \%$ and $16.6 \%$ respectively. The real commuting distances, however, are significantly shorter (a mean route length of $17.5 \mathrm{~km}$ and 18.5 minutes by car), which can be ascribed to commuting costs. A simple example presented in the article suggests that real commuting behaviour represents a compromise between an economically rational preference for short commuting distance and the need to find suitable employment. On the other hand, wage returns to commuting within Ostrava's labour market were found to be linear, which may be connected with its limited size and thus different job-searching processes. It can be concluded that both inter-urban and intraurban commuting pay off in the Czech Republic, although there are significant differences between them. From a methodological point of view, this article has explored the suitability of data provided by the on-line application Mapy. cz for the approximation of commuting time and distance. A comparison of the data and results from different datasets, combining real and approximated data on commuting, suggests that data from the Mapy.cz application represents a suitable approximation for missing or limited data on commuting.

\section{Acknowledgements}

This research was supported by SGS grant from the VSBTechnical University of Ostrava (grant number SP2020/116). Authors would like to thank Simon Johnson for a detailed proofreading.

\section{Supplementary material}

The Appendixes 1 and 2 are available at: https://cdrive.vsb. cz/index.php/s/bDzxTnGEKfwntxe

\section{References:}

BALCAR, J. (2012): Supply Side Wage Determinants: Overview of Empirical Literature. Review of Economic Perspectives, 12(4): 207-222.

BARTUS, T. (2011): Commuting time, wages and reimbursement of travel costs. Evidence from Hungary. Review of Sociology of the Hungarian Sociological Association, 21(4): 72-94.

CARRA, G., MULALIC, I., FOSGERAU, M., BARTHELEMY,M. (2016): Modelling the relation between income and commuting distance. Journal of the Royal Society Interface, 13(119): 1-8.

ČSO (2013): Dojižd'ka do zaměstnání a škol podle Sčítání lidu, domů a bytů - Česká republika - 2011 [online]. Czech Statistical Office [cit. 16.09.2019]. Available at: https:// www.czso.cz/csu/czso/dojizdka-do-zamestnani-a-skolpodle-scitani-lidu-domu-a-bytu-2011-ceska-republika2011-6elqhrcwol

EKBERG, J., WIDEGREN, D. (2019): The Wage Effect of Commuting - An Analysis of the Gender Wage Gap in Local Labour Markets. Nordic Statistical Meeting Helsinki 26.-28. 8. 2019.
GERLACH, K., STEPHAN, G. (1992): Commuting time and wages - An analysis with individual data for the Federal Republic of Germany. Jahrbucher fur Nationalokonomie und Statistik, 210: 18-34.

HAIDER, M., KERR, K., BADAMI, M. (2013): Does commuting cause stress? The public health implications of traffic congestion [online]. [cit. 16.09.2019]. Available at: https://papers.ssrn.com/sol3/papers.cfm?abstract_ id $=2305010$

HARRIS, J. R., TODARO, P. M. (1970): Migration, Unemployment and Development. A Two Sector Analysis. The American Economic Review, 60(1): 126-142.

HAZANS, M. (2004): Does commuting reduce wage disparities? Growth \& Change, 35: 360-390.

HICKS, J. R. (1932): The theory of wages. London, Macmillan.

HIGGINS, C. D., SWEET, M. N., KANAROGLOU, P. S. (2018): All minutes are not equal: Travel time and the effects of congestion on commute satisfaction in Canadian cities. Transportation, 45: 1249-1268.

CHOI, J., COUGHLIN, J. F., D’AMBROSIO, L. (2013): Travel time and subjective well-being. Transportation Research Record: Journal of the Transportation Research Board. 2357: 100-108.

JOHNSTON, R., GREGORY, D., PRATT, G., WATTS, M. (2009): The Dictionary of Human Geography. Oxford, Blackwell Publishing.

KLUGER, A. N. (1998): Commute variability and strain. Journal of Organizational Behavior, 19: 147-165.

KREJČÍ, T., TOUŠEK, V. (2004): Vliv dojížd'ky za prací na situaci na trhu práce ve městě Brně. In: Sborník referátů z VII. mezinárodního kolokvia o regionálních vědách (pp. 95-101). Brno, Masarykova univerzita.

LAIRD, J. (2006): Commuting Costs and their Impact on Wage Rates. Institute of Transport Studies, University of Leeds, Working Paper 587.

LEIGH, P. J. (1986): Are compensating wages paid for time spent commuting? Applied Economics, 18: 1203-1213.

LEWIS, W. A. (1954): Economic Development with Unlimited Supplies of Labour. The Manchester School of Economic and Social Studies, 22: 139-191.

MANNING, A. (2003): The real thin theory: Monopsony in modern labour markets. Labour Economics, 10: 105-131.

MINCER, J. (1978): Family Migration Decisions. Journal of Political Economy, 86(5).

MORRIS, E. A., ZHOU, Y. (2018): Are long commutes short on benefits? Commute duration and various manifestations of well-being. Travel Behaviour and Society, 11: 101-110.

MUlALIC, I., VAN OMMEREN, J. N., PILEGAARD, N. (2014): Wages and commuting: Quasi-natural experiments' evidence from firms that relocate. The Economic Journal, 124: 1086-1105.

NIE, P., SOUSA-POZA, A. (2018): Commute time and subjective well-being in urban China. China Economic Review, 48: 188-204.

NIEBUHR, A., GRANATO, N., HAAS, A., HAMANN, S. (2012): Does labour mobility reduce disparities between regional labour markets in Germany? Regional Studies, 46: 841-858. 
NOVÁK, V. (2005): Pracovní migrace a regiony dojížd’ky za prací v kraji Vysočina. In: Sborník příspěvků z I. mezinárodní Batovy regionalistické conference (pp. 7580). Zlín, Univerzita Tomáše Bati.

PIORE, M. (1979): Birds of Passage: Migrant Labor and Industrial Societies. Cambridge, Cambridge University Press.

PLAUT, P. O. (2006): The intra-household choices regarding commuting and housing. Transportation Research: Part A: Policy and Practice, 40: 561-571.

RANIS, G., FEI, J.C.H. (1961): A Theory of Economic Development. American Economic Review, 51: 533-565.

RENKOW, M., HOOVER, D. (2000): Commuting, migration, and rural-urban population dynamics. Journal of Regional Science, 40: 261-287.

ROSS, S. L., ZENOU, Y. (2008): Are shirking and leisure substitutable? An empirical test of efficiency wages based on urban economics theory. Regional Science and Urban Economics, 38: 498-517.

ROUWENDAL, J. (1999): Spatial job search and commuting distances. Regional Science and Urban Economics, 29: 491-517.

SANDOW, E., WESTIN, K. (2010): The persevering commuter - Duration of long-distance commuting. Transportation Research Part A: Policy \& Practice, 44: 433-445.

SJAASTAD, L.A. (1962): The Costs and Returns of Human Migration. The Journal of Political Economy, 70(5): 80-93.

SPOSATO, R. G., RÖDERER, K., CERVINKA, R. (2012): The influence of control and related variables on commuting stress. Transportation Research Part F: Traffic Psychology and Behaviour, 15: 581-587.
STIGLER, G. J. (1961): The economics of information. The Journal of Political Economy, 69(3): 213-225.

STUTZER, A., FREY, B. S. (2008): Stress that doesn't pay: The commuting paradox. Scandinavian Journal of Economics, 110: 339-366.

TERMOTE, M. (1980): Migration and Commuting: A theoretical framework. IIASA Working paper, No. WP-80-069.

TESLA, J., HORÁK, J. (2015): Prostorové interakce vybraných krajských měst a okolních obcí. In: Symposium GIS Ostrava 2015 - Současné výzvy geoinformatiky. Ostrava: VŠB - Technická univerzita Ostrava, pp. 1-10.

TIJDENS, K. G., OSSE, P. (2019): Wage Indicator continuous web-survey on work and wages. Amsterdam: University of Amsterdam/AIAS and Stichting Loonwijzer [online]. [cit. 16.09.2019]. Available at: https://data-sets.iza.org/ data-set/59/wageindicator-survey

TIMOTHY, D., WHEATON, W. C. (2001): Intra-urban wage variation, employment location, and commuting times. Journal of Urban Economics, 50: 338-366.

TODARO, M. P. (1969): A Model for Labour Migration and Urban Unemployment in Less Developed Countries. American Economic Review, 59(1): 138-148.

TOUŠEK, V., KUNC, J. (1999). Transformace průmyslové výroby a její vliv na dojížd'ku za prací. In: Sborník příspěvků z Mezinárodního slovensko-česko-polského semináře (pp. 65-74). Bratislava, Univerzita Komenského. 